\title{
PENGEMBANGAN POTENSIAL KESEHATAN ANAK MELALUI SCREENING DETEKSI DINI TUMBUH KEMBANG (DDTK) DAN PERILAKU HIDUP BERSIH SEHAT
}

\author{
Fatsiwi Nunik Andari ${ }^{1}$, Lussyefrida Yanti $^{2}$, Panzilion $^{3}$ \\ ${ }^{1,2,3}$ Program Studi Ilmu Keperawatan \\ Fakultas Ilmu Kesehatan Universitas Muhammadiyah Bengkulu \\ Coresponden author : fatsiwiandari@umb.ac.id, lussyefrida@umb.ac.id, \\ panzilion@umb.ac.id,
}

\begin{abstract}
ABSTRAK
Golden Age merupakan masa yang sangat penting bagi pertumbuhan dan perkembangan anak pada usia 1-6 tahun. Masa kanak-kanak ini memberikan pengaruh yang besar pada seorang individu dalam tahapan perkembangan selanjutnya. Tahapan perkembangan anak meliputi beberapa aspek, salah satunya aspek fisik motorik. Perkembangan pada aspek fisik motorik anak diartikan sebagai perubahan bentuk tubuh pada anak yang berpengaruh terhadap keterampilan gerak, khususnya dalam hal ini adalah keterampilan dalam melakukan perilaku hidup bersih dan sehat melalui kegiatan cuci tangan yang benar. Mencuci tangan adalah membasuh kedua telapak tangan dengan sabun dan air mengalir sebelum dan sesudah melakukan tindakan dengan tujuan untuk menghilangkan kuman. Membiasakan mencuci tangan sejak dini merupakan langkah awal untuk mencegah masuknya kuman dan resiko tertularnya penyakit. Upaya yang dapat dilakukan untuk mengetahui tumbuh kembang anak antara lain dengan melakukan kegiatan screening atau pendeteksian secara dini. Upaya lain yang dapat dilakukan adalah dengan memberikan stimulasi-stimulasi perkembangan anak baik dengan permainan ataupun kegiatan belajar yang menyenangkan. Kegiatan ini bertujuan untuk mengetahui tumbuh kembang anak di masa emasnya, mencegah terjadinya gangguan tumjbuh kembang secara dini dan mencegah penyakitakibat tidak mencuci tangan dengan benar. Sasaran pada pelaksanaan kegiatan ini adalah anak-anak TK Aisyiyah Bustanul Athfal IV Kelurahan Sukamerindu Kota Bengkulu. Tahapan kegiatan dimulai dengan melakukan analisa situasi, melakukan penilaian screening tumbuh kembang anak, memberikan penyuluhan kesehatan tentang cuci tangan yang benar sekaligus melakukan demonstrasi cara mencuci tangan yang benar, dan mendampingi kegiatan-kegiatan yang berkaitan dengan aktivitas perkembangan anak. Dari hasil evaluasi kegiatan didapatkan gambaran tumbuh kembang anak-anak TK TK Aisyiyah Bustanul Athfal IV Kelurahan Sukamerindu Kota Bengkulu normal atau sesuai dengan usianya, serta terdapat peningkatan pengetahuan dan pemahaman anak-anak TK Aisyiyah Bustanul Athfal IV tentang cara mencuci tangan yang benar.
\end{abstract}

Kata Kunci : Cuci tangan, Screening, Tumbuh kembang anak

\section{PENDAHULUAN}

Golden Age merupakan masa yang sangat penting bagi pertumbuhan dan perkembangan anak pada usia 1-6 tahun.
Masa kanak-kanak ini memberikan pengaruh yang besar pada seorang individu dalam tahapan perkembangan selanjutnya (Sugiono \& Kuntjojo, 2016). 


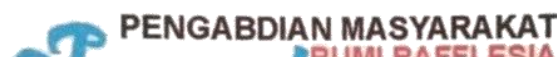 Ourrate}

Menurut The Convention On The Right Of The Child tahun 2014, periode perkembangan anak-anak terdiri dari masa neonatus usia (0-28 hari), bayi (1-1 tahun), toodler (1-3 tahun), usia prasekolah (3-5 tahun), usia sekolah (612 tahun), hingga remaja usia (12-18 tahun). Suatu bangsa memerlukan penerus yang berkualitas yang bisa membuat bangsanya berkembang dan maju. Kualitas generasi penerus bangsa tergantung dari kualitas tumbuh kembang anak, terutama usia toddler (1-3) tahun, dimana pada usia ini anak menunjukkan perkembangan otak yang sangat signifikan. Oleh sebab itu kualitas tumbuh kembang balita di Indonesia perlu mendapat perhatian khusus, salah satunya dengan upaya pembinaan yang tepat yang akan berdampak pada pertumbuhan dan perkembangan anak yang berkualitas (Kemenkes RI, 2016).

Kualitas yang baik akan tercipta jika sumber daya manusia diberikan pengawasan mulai dari usia anak-anak, dimana pada usia ini anak sudah belajar percaya kepada orang lain, mulai cepat meniru dan mengembangkan kemandirian yang dimilikinya (Sari, 2017). Tumbuh kembang anak meliputi beberapa aspek, salah satunya aspek fisik motorik. Aspek fisik diartikan sebagai jasmani, badan, tubuh sedangkan aspek motorik diartikan dengan penggerak. Jadi perkembangan fisik motorik anak diartikan sebagai perubahan bentuk tubuh pada anak yang berpengaruh terhadap keterampilan gerak, khususnya dalam hal ini adalah keterampilan anak dalam melakukan cuci tangan yang benar (Soetjiningsih, 2013).

Anak dengan tahapan tumbuh kembang yang baik akan terhindar dari gangguan perkembangan anak seperti gangguan bicara dan bahasa yang diperkirakan angka kejadiannya berkisar antara $1,0 \%$ - 32,0\%, cerebral palsy sekitar 1 - 5 per 1000 anak, down sindrom yaitu 1 per 1000 anak, retardasi mental sekitar $0,3 \%$ - 0,4\%, gangguan pemusatan perhatian dan hiperaktivitas sebesar 4,0\%-12,0\% (Soetjiningsih, 2013).

Salah satu tempat terkenanya penyakit dikalangan anak-anak yaitu di sekolahan. Anak usia sekolah ataupun anak yang sudah mengenal sekolah merupakan anak yang rawan terserang penyakit. Karena anak-anak banyak berinteraksi dengan orang lain ataupun lingkungan sekitarnya. Penyakit tersebut biasanya seperti, diare, cacingan dan anemia (Setyaningrum, Rofi'i, Setyanti, 2016).

Anak usia sekolah sangat menyukai kegiatan atau aktivitas bermain baik di lingkungan sekolah maupun di lingkungan rumah. Aktivitas bermain ini dapat dilakukan bila anak dalam keadaan yang sehat, sebaliknya bila anak dalam kondisi yang sedang sakit, anak menjadi lemas dan hanya terbaring di tempat tidur dengan kerewelannya. Kondisi sehatdan sakit seorang anak turut dipengaruhi oleh perilaku sehari-hari dalam kegiatan bermainnya termasuk perilaku mencuci tangan setelah anak selesai bermain. Mencuci tangan adalah proses yang secara mekanis melepaskan kotoran dan debris dari kulit tangan dengan menggunakan sabun biasa dan air (Kemenkes RI, 2015).

Mencuci tangan adalah membasuh kedua telapak tangan dengan sabun dan air mengalir sebelum dan sesudah melakukan tindakan dengan tujuan untuk menghilangkan kuman. Membiasakan mencuci tangan sejak dini merupakan langkah awal untuk mencegah masuknya kuman dan resiko tertularnya penyakit yang dapat mempengaruhi tumbuh kembang seorang anak. Cara yang mudah dan efektif untuk menghindari berjangkitnya berbagai macam virus penyebab penyakit yang menempel pada tangan yaitu dengan mencuci tangan yang benar dan tepat. Mencuci tangan menggunakan sabun lebih efektif dalam 
hal menghilangkan kotoran dan debudebu yang menempel pada permukaan kulit (Desiyanto \& Djannah, 2013)

Jadi melakukan deteksi dini pertumbuhan dan perkembangan anak serta mengajarkan anak untuk mencuci tangan yang benar sangatlah penting untuk menciptakan anak-anak yang sehat. Deteksi dini merupakan upaya penjaringan yang dilaksanakan secara komprehensif untuk mengetahui adanya penyimpangan pada tumbuh kembang anak serta untuk mengkoreksi adanya faktor resiko. Dengan adanya faktor resiko yang telah diketahui, maka upaya untuk meminimalkan dampak pada anak bisa dicegah. Upaya pencegahan tersebut diberikan sesuai dengan umur perkembangan anak. Dengan melakukan deteksi dini tumbuh kembang pada anak maka dapat diketahui secara dini ada tidaknya gangguan tumbuh kembang yang terjadi pada anak, apakah tumbuh kembang anak saat ini berada dalam kondisi yang normal, abnormal, meragukan, atau menyimpang sehingga apabila ada gangguan atau penyimpangan dapat ditangani dengan benar dan cepat untuk mencegah akibat yang lebih fatal di kemudian hari. Jika penyimpangan tumbuh kembang terlambat diketahui, maka penanganannya akan jauh lebih sulit (Soetjiningsih, 2013).

Tujuan diselenggarakannya kegiatan pengabdian pada masyarakat ini adalah untuk mengetahui gambaran tumbuh kembang anak-anak TK Aisyiyah Bustanul Athfal IV Kelurahan Sukamerindu Kota Bengkulu serta anakanak TK tersebut dapat belajar dan memahami bagaimana cara mencuci tangan yang benar sehingga diharapkan anak-anak TK tersebut dapat tumbuh dan berkembang secara sehat dan sejahtera agar menjadi sumber daya manusia yang berkualitas di masa depan.

Salah satu bentuk kegiatan yang dapat dilakukan oleh tenaga kesehatan adalah melakukan screening atau penilaian, pemantauan dan pembinaan tumbuh kembang anak serta menganjurkan kepada orang tua untuk dapat memberikan stimulasi rutin sedini mungkin secara terus menerus kepada anaknya. Berdasarkan hasil penelitian Thaariq (2014), pemberian stimulasi perkembangan motorik kasar dan halus berpengaruh terhadap perkembangan bayi usia 3-6 bulan.

Bentuk kegiatan lain yang dapat ilakukan adalah memberikan pendidikan kesehatan. Pendidikan kesehatan merupakan suatu proses yang direncanakan untuk mempengaruhi atau mengajak orang lain, baik individu, kelompok atau masyarakat agar melaksanakan perilaku hidup sehat (Nursalam \& Efendi, 2008). Hal ini sejalan dengan hasil penelitian Susilaningsih \& Hadiatama (2017) dimana ada pengaruh pemberian pendidikan kesehatan tentang cuci tangan terhadap tingkat pengetahuan dan perilaku mencuci tangan siswa SD Negeri 01 Gonilan Kartasura Sukoharjo.

Oleh karena itu pengabdian yang bertujuan untuk menilai tumbuh kembang anak di masa emasnya dan meningkatkan pengetahuan dasar anak tentang mencuci tangan yang benar sangat penting dilakukan untuk mencegah terjadinya penyimpangan pertumbuhan dan per kembangan serta mencegah munculnya berbagai jenis penyakit yang bermula dari bersarangnya kuman-kuman di tangan anak.

\section{METODE KEGIATAN}

Kegiatan ini dilaksanakan di TK Aisyiyah Bustanul Athfal IV Kelurahan Sukamerindu Kota Bengkulu mulai tanggal 18-21 November 2019 yang diikuti oleh seluruh anak-anak dan guru TK Aisyiyah Bustanul Athfal IV Kota Bengkulu.

Pelaksanaan kegiatan dimulai dengan melakukan analisis situasi terlebih dahulu untuk mengetahui 


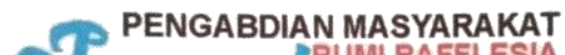 Ournater}

sejauhmana persiapan TK dalam pelaksanaan kegiatan pengabdian ini. Kegiatan dilanjutkan dengan melakukan penilaian tumbuh kembang anak-anak TK Aisyiyah Bustanul Athfal IV Kota Bengkulu dengan menggunakan kuesioner KPSP yang dilakukan selama 2 hari. Selanjutnya dilakukan kegiatan pemberian pendidikan kesehatan atau penyuluhan tentang cara mencuci tangan yang benar dengan 6 langkah cuci tangan berdasarkan pedoman dari Badan Kesehatan Dunia atau WHO (World Health Organization). Pendidikan kesehatan atau penyuluhan dilakukan untuk menambah pengetahuan anak-anak TK tentang definisi mencuci tangan, tujuan dilakukannya cuci tangan, waktu yanag tepat untuk mencuci tangan, dan 6 langkah mencuci tangan yang benar. Kegiatan penyuluhan kesehatan ini dilakukan dengan metode ceramah disertai dengan pemutaran video cara mencuci tangan yang benar dan dampak penyakit yang dapat terjadi jika tidak mencuci tangan. Tujuan pemutaran video ini agar anak-anak TK menjadi lebih tertarik, lebih fokus dan lebih paham akan materi yang disampaikan. Untuk lebih menambah pemahaman anak-anak TK, kegiatan ini disertai juga dengan demonstrasi gerakan 6 langkah mencuci tangan yang benar.

Kegiatan selanjutnya adalah melakukan pendampingan kegiatan anakanak TK serta menyampaikan hasil penilaian tumbuh kembang anak-anak kepada guru-guru kelas yang ikut berpartisipasi dalam kegiatan ini. Dari hasil kegiatan ini, diharapkan para guru agar terus melakukan stimulasi dan pendampingan untuk setiap kegiatan anak yang berkaitan dengan peningkatan pertumbuhan dan perkembangan anak.

\section{HASIL DAN PEMBAHASAN}

a. Kegiatan Awal

Dihari pertama dilakukan kegiatan serah terima tim pengabdian dan analisis situasi di TK Aisyiyah Bustanul Athfal IV Kota Bengkulu. Kegiatan awal ini dilaksanakan pada tanggal 18 November 2019 yang diikuti oleh 12 orang yang terdiri dari kepala sekolah, guru, staf TK Aisyiyah Bustanul Athfal IV Kota Bengkulu dan tim pengabdian dari Prodi Ners Fakultas Ilmu Kesehatan Universitas Muhammadiyah Bengkulu.

Harapan dari kegiatan ini adalah tercapainya tujuan dari analisis situasi dengan baikdan agar civitas akademik TK Aisyiyah Bustanul Athfal IV Kota Bengkulu, khususnya anak-anak TK sekitar dapat menerima keberadaan tim Pengabdian dan mengikuti setiap program kegiatan yang akan dilakukan oleh tim pengabdian di TK tersebut mulai dari kegiatan analisis situasi, penilaian tumbuh kembang anak, pemberian pendidikan kesehatan tentang mencuci tangan yang benar, dan kegiatan pendampingan kegiatan anak di sekolah.

Berikut adalah dokumentasi kegiatan sebelum dilaksanakanya kegiatan awal pengabdian:

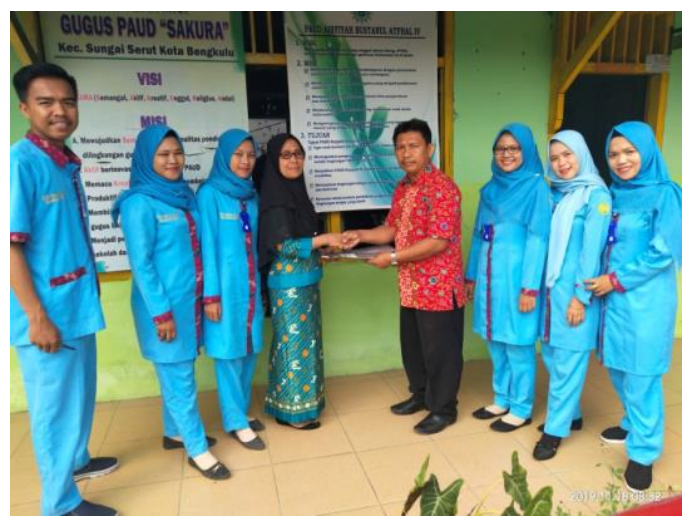

Dokumentasi Serah Terima Tim Pengabdian Kepada Kepala Sekolah TK Aisyiyah Bustanul Athfal IV Kota Bengkulu

b. Kegiatan Penilaian Tumbuh Kembang Kegiatan penilaian tumbuh kembang dilakukan pada anak-anak 


\section{Ournalism}

di TK Aisyiyah Bustanul Athfal IV Kelurahan Sukamerindu Kota Bengkulu. Kegiatan ini berlangsung selama 2 hari mengingat jumlah anak TK yang cukup banyak dan waktu belajar mereka yang tidak begitu lama di sekolah. Kegiatan penilaian tumbuh kembang ini dilaksanakan pada tanggal 19-20 November 2019. Setelah kegiatan tersebut dilaksanakan dilanjutkan dengan kontrak waktu dengan pihak sekolah untuk pelaksanaan pendidikan kesehatan atau penyuluhan kesehatan tentang cara mencuci tangan yang benar yang dilakukan oleh tim pengabdian.

Kegiatan pengabdian ini memiliki tema Pengembangan Potensial Kesehatan Anak Melalui Screening Deteksi Dini Tumbuh Kembang (DDTK) dan Perilaku Hidup Bersih Sehat dengan Mencuci Tangan yang Benar. Hasil dari kegiatan penilaian tumbuh kembang anak ini didapatkan semua anak TK Aisyiyah Bustanul Athfal IV Kota Bengkulu memiliki tumbuh kembang yang normal atau sesuai dengan usianya saat ini. Tidak ada anak TK yang memiliki keterlambatan atau penyimpangan dalam tumbuh kembangnya saat ini.

Berikut dokumentasi kegiatan penilaian tumbuh kembang anak TK oleh tim pengabdian :

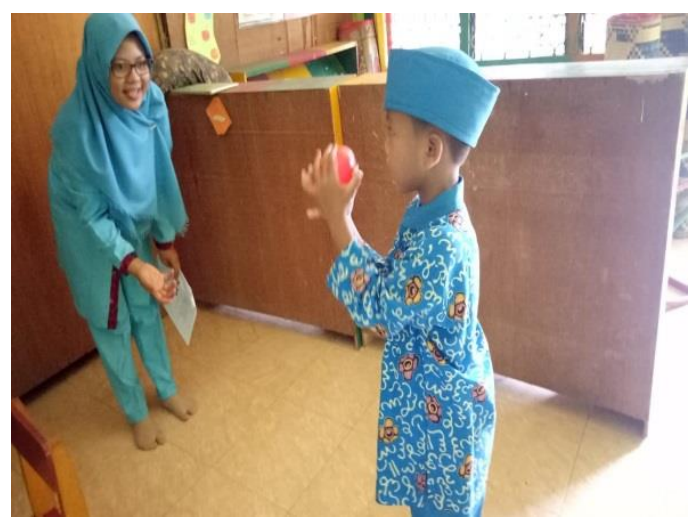

Dokumentasi penilaian perkembangan kemampuan motorik kasar anak

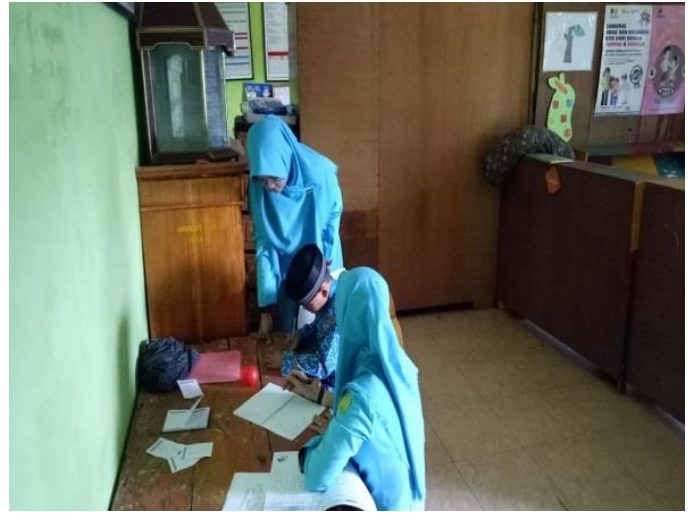

Dokumentasi penilaian perkembangan kemampuan motorik halus anak

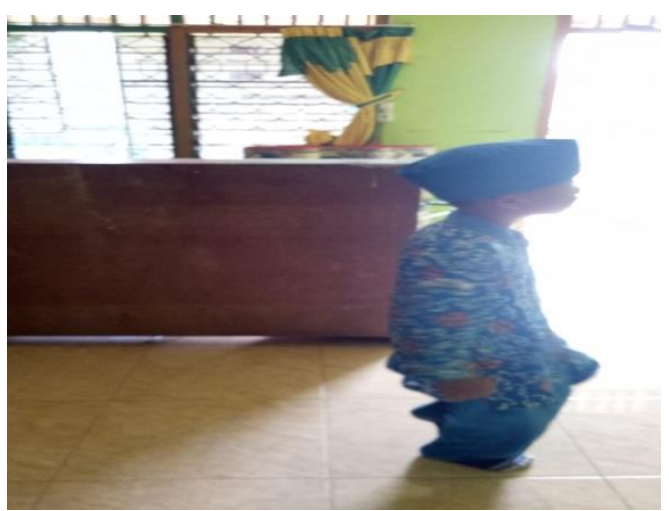

Dokumentasi penilaian pertumbuhan anak

c. Kegiatan Pemberian Pendidikan Kesehatan Tentang Cuci Tangan

Pelaksanaan kegiatan pemberian pendidikan kesehatan dilakukan tim pengabdian pada tanggal 21 November 2019 pukul 09.00WIB sampai dengan selesai. Pelaksanaan penyuluhan kesehatan dilaksanakan di ruang kelas yang dimulai dengan menjelaskan maksud dan tujuan kegiatan, kemudian dilanjutkan dengan pemutaran video tentang pentingnya cuci tangan dan dampak yang bisa terjadi bila tidak mencuci tangan. Selanjutnya dilakukan pemaparan materi tentang cuci tangan, termasuk di dalamnya bagaimana cara mencuci tangan yang benar dengan 6 langkah oleh Tim Pengabdian dan melakukan demonstrasi secara langsung cara 
mencuci tangan yang benar serta meminta audiens (anak-anak TK) melakukan bersama-sama dan mengulangi kembali gerakan cara mencuci tangan tersebut sehingga bisa diketahui bagaimana pemahaman anak-anak TK terhadap materi yang sudah diberikan.

Kegiatan pemberian pendidikan kesehatan tentang mencuci tangan yang benar ini diikuti oleh 32 orang yang terdiri dari anak-anak TK dan guru-guru serta mahasiswa dan Tim Pengabdian Masyarakat. Hasil dari kegiatan penyuluhan kesehatan ini didapatkan gambaran bahwa anakanak TK belum mengetahui 6 langkah cuci tangan yang benar sesuai anjuran dari WHO. Anak-anak pada umumnya hanya melakukan cuci tangan biasa dengan hanya menggosok-gosokkan kedua tangannya saja dengan air tanpa mengetahui tehnik saat menggosokgosokkan tangan tersebut.

Berikut dokumentasi kegiatan pelaksanaan penyuluhan kesehatan mulai dari pemutaran video, penyampaian materi dan sesi tanya jawab antara tim pengabdian dengan anak-anak TK, serta pembagian leaflet materi penyuluhan:

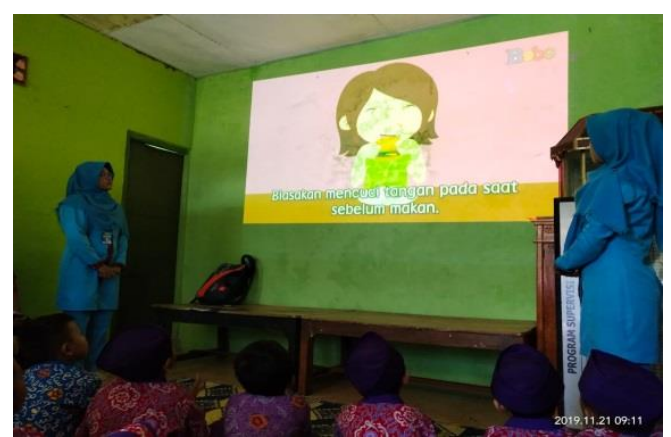

Dokumentasi pemutaran video terkait cuci tangan

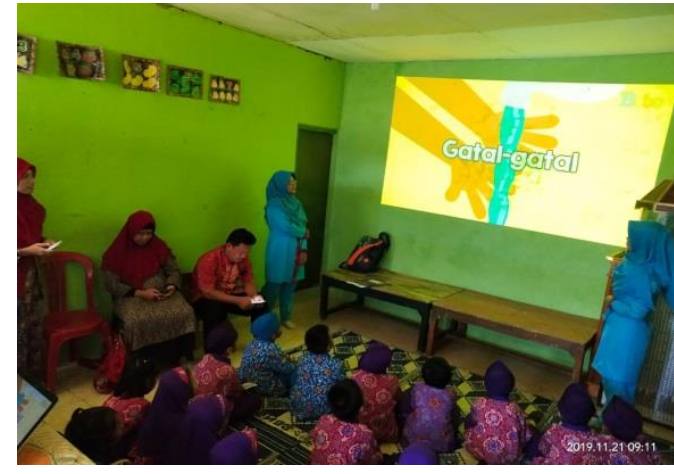

Dokumentasi penyuluhan kesehatan tentang mencuci tangan

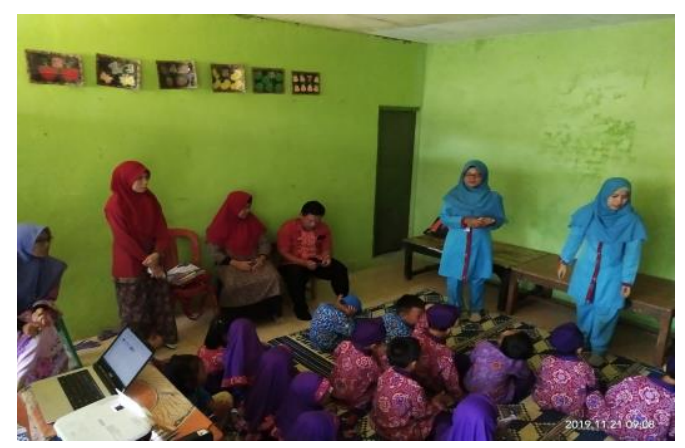

Dokumentasi sesi tanya jawab terkait materi penyuluhan

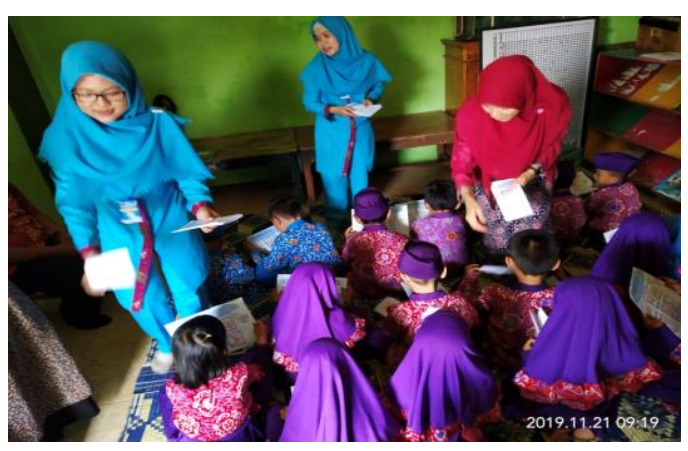

Dokumentasi pembagian leaflet materi penyuluhan kesehatan

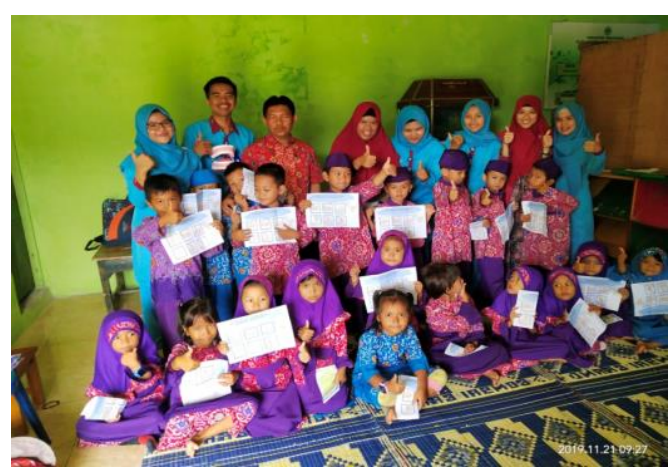

Dokumentasi selesai melaksanakan penyuluhan kesehatan 


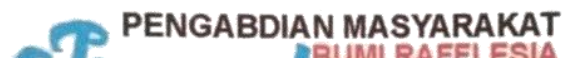 Ournats=}

d. Kegiatan Pendampingan Aktivitas Anak

Kegiatan pendampingan aktivitas anak yang dilakukan oleh tim pengabdian antara lain pendampingan dalam belajar membaca, belajar mengaji, menggambar, senam sehat bersama, dan bermain. Kegiatan pendampingan aktivitas anak ini bertujuan untuk menstimulasi kemampuan motorik kasar, motorik halus, interaksi sosial atau personal sosial anak dengan teman, guru dan orang lain dalam hal ini adalah tim pengabdian yang baru mereka kenal serta menstimulasi kemampuan bahasa anak agar dapat berkembang dengan semakin baik.

Pelaksanaan

kegiatan pendampingan aktivitas anak ini dilaksanakan selama 2 hari yaitu pada tanggal 22 dan 23 November 2019 mulai dari awal jam pembelajaran anak di sekolah yaitu pukul 08.00 WIB sampai berakhirnya jam pelajaran sekolah yaitu sekitar pukul 10.00WIB. dalam kegiatan pendampingan aktivitas anak-anak TK ini turut terlibat juga guru-guru kelas yang mengajara di TK Aisyiyah Bustanul Athfal Kelurahan Sukamerindu Kota Bengkulu. Dalam kegiatan pendampingan ini, tim pengabdian membagi diri ke beberapa anak TK.

Kegiatan pendampingan berupa senam sehat bersama dilaksanakan di halaman depan TK dan diikuti oleh anak-anak TK dengan sangat antusias dan gembira. Anak-anak TK mencoba mengikuti setiap gerakan dari instruktur senam dengan baik Anak-anak TK memperhatikan dengan seksama setiap gerakan yang dicontohkan oleh instruktur. Senam sehat bersama ini selain diikuti oleh seluruh anak-anak TK, diikuti juga oleh guru-guru dan staf TK Aisyiyah Bustanul Athfal serta tim pengabdian.
Hal ini menambah semangat dalam pelaksanaan kegiatan.

Kegiatan senam sehat bersama ini bertujuan untuk melatih anak-anak dalam melakukan kontrol gerak tubuhnya, melatih otot-otot gerak tangan dan kaki anak, melatih anak untuk dapat mensinkronkan gerakan yang mereka lihat dengan gerakan pada dirinya serta melatih kemampuan anak dalam menciptakan keseragaman gerakan mengikuti irama yang didengar. Selain itu kegiatan ini juga diharapkan dapat menjaga kebugaran dan kesehatan anak-anak TK sehingga dapat mendukung semangat anak dalam belajar.

Berikut dokumentasi pelaksanaan senam sehat bersama oleh tim pengabdian:

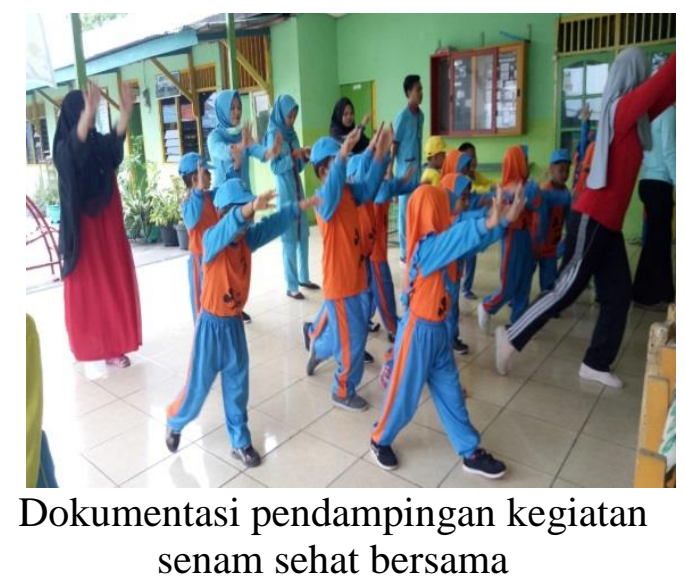

Kegiatan pendampingan lainnya adalah dalam aktivitas keseharian anak-anak TK Aisyiyah Bustanul Athfal di sekolah yang didampingi oleh mahasiswa Ners sebagai bagian (anggota) dari tim pengabdian pada masyarakat ini. Pendampingan tersebut berupa pendampingan dalam aktivitas belajar anak seperti belajar mengaji yang didampingi oleh Desti Nopriga Yanti, aktivitas belajar mengenal huruf atau membaca yang didampingi oleh Hazaroh Eldis Sabrina, aktivitas belajar menulis atau 
membuat garis yang didampingi oleh Restu, aktivitas berinteraksi yang didampingi oleh Ervian Saputra, dan aktivitas bermain lainnya yang didampingi oleh Yesi dan Yulfitria.

Berikut beberapa dokumentasi pelaksanaan kegiatan pendampingan aktivitas anak -anak TK yang dilakukan oleh tim pengabdian:

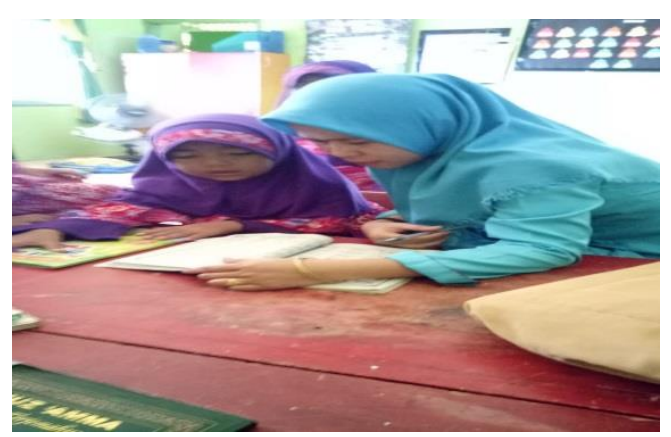

Dokumentasi kegiatan

pendampingan belajar mengaji oleh tim pengabdian

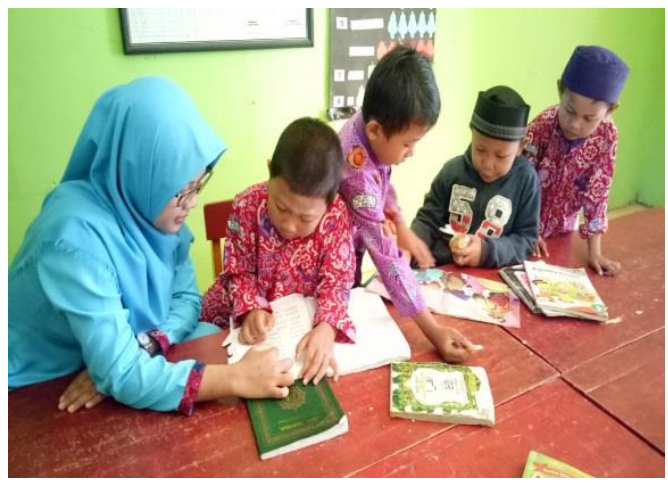

Dokumentasi kegiatan

pendampingan belajar membaca oleh tim pengabdian

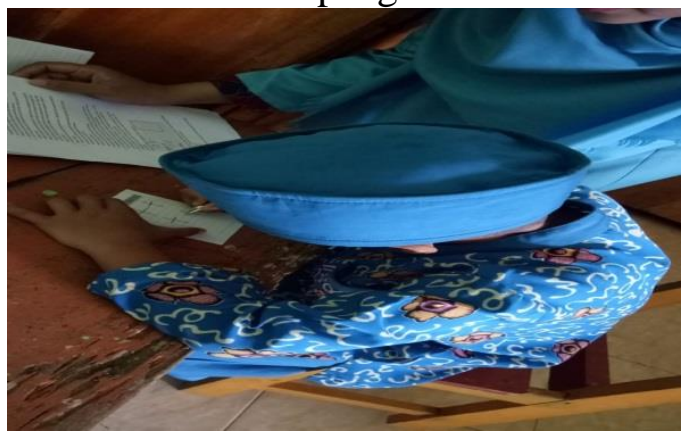

Dokumentasi kegiatan pendampingan belajar menulis/ membuat garis oleh tim pengabdian

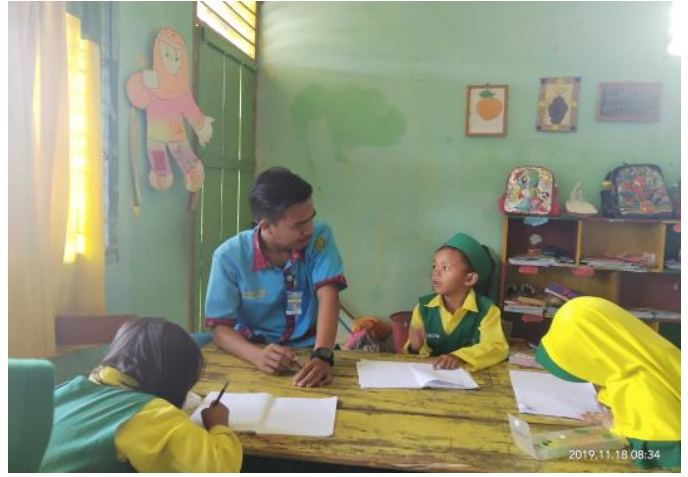

Dokumentasi kegiatan pendampingan berinteraksi oleh tim pengabdian
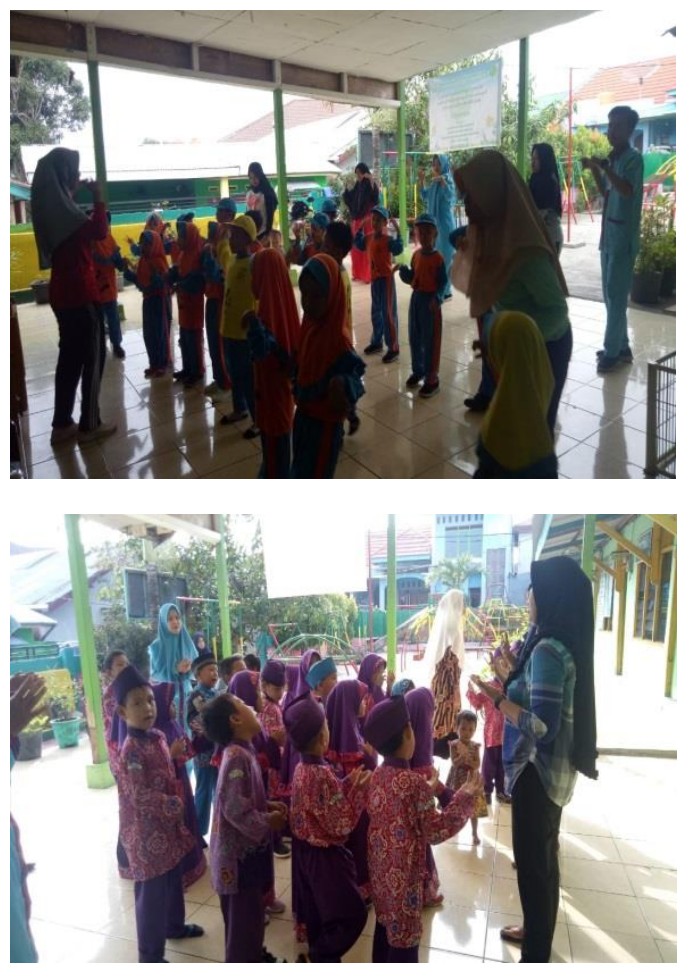

Dokumentasi kegiatan pendampingan aktivitas bermain oleh tim pengabdian

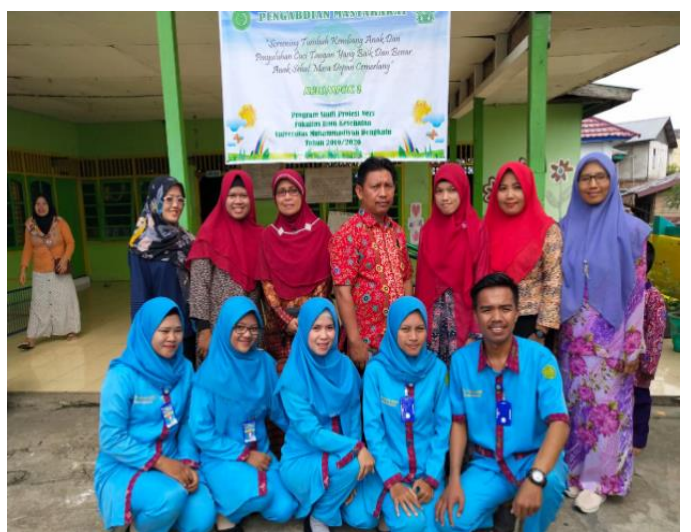


Dokumentasi Tim Pengabdian Masyarakat bersama Kepala Sekolah dan Guru TK Aisyiyah Bustanul Athfal Kelurahan Sukamerindu Kota Bengkulu

E. Kegiatan Akhir

Kegiatan akhir pengabdian masyarakat di TK Aisyiyah Bustanul Athfal lokakarya akhir dilaksanakan pada hari Sabtu tanggal 23 November 2019 mulai pukul 08.00 WIB sampai dengan selesai. Kegiatan ini diikuti oleh kurang lebih 25 orang yang terdiri dari anak-anak TK, Kepala sekolah dan guru TK serta tim pengabdian masyarakat. Dalam kegiatan ini disampaikan terkait hasil seluruh kegiatan yang sudah dilakukan tim pengabdian masyarakat, dimulai dari kegiatan serah terima dan analisis situasi terkait lokasi dan kondisi anak-anak di TK Aisyiyah Bustanul Athfal, kegiatan penilaian tumbuh kembang anak-anak TK, pelaksanaan penyuluhan kesehatan tentang cara mencuci tangan yang benar, senam sehat bersama dan pendampingan aktivitas kegiatan anak-anak TK di sekolah meliputi pendampingan dalam kegiatan belajar mengaji, belajar membaca, belajar menggambar atau menulis, berinterkasi sosial dan aktivitas bermain.

Dalam kegiatan ini juga tim pengabdian masyarakat mohon izin berpamitan dan mengucapkan terima kasih kepada pihak sekolah yang telah memberikan kesempatan bekerjasama dengan tim pengabdian masyarakat Program Studi Ners Fakultas Ilmu Kesehatan Universitas Muhammadiyah Bengkulu untuk dapat mengaplikasikan ilmu pengetahuan yang sudah didapatkan di akademik ke tengah masyarakat secara langsung. Selain itu pada kesempatan ini tim pengabdian masyarakat juga menyampaikan permohonan maaf kepada pihak sekolah apabila terdapat tutur kata dan sikap yang kurang berkenan selama melakukan kegiatan pengabdian masyarakat di TK Aisyiyah Bustanul Athfal Kelurahan Sukamerindu Kota Bengkulu ini.Tim Pengabdian berharap kerjasama ini dapat terus berlanjut di masa yang akan datang.

\section{PENUTUP}

\section{Kesimpulan}

Hasil dari pelaksanaan kegiatan pengabdian masyarakat ini adalah:

1. Kegiatan awal dimulai dengan serah terima tim pengabdian kepada kepala sekolah TK Aisyiyah Bustanul Athfal. Selanjutnya pada kegiatan awal ini dilakukan analisis situasi untuk mengetahui gambaran lokasi dan sasaran pengbdian masyarakat, yang dalam hal ini adalah anakanak TK Aisyiyah Bustanul Athfal. Kegiatan ini diikuti oleh 12 orang yang terdiri dari kepala sekolah, guru, staf TK dan tim pengabdian. Pada kegiatan awal ini juga disampaikan rangkaian kegiatan yang akan dilakukan mulai dari penilaian tumbuh kembang anak TK, pendidikan kesehatan tentang cara mencuci tangan yang benar, dan kegiatan pendampingan aktivitas anak yang menunjang peningkatan kemampuan perkembangan anak TK selama di sekolah.

2. Kegiatan penilaian tumbuh kembang anak dilaksanakan selama dua hari dengan menggunakan kuesioner KPSP. Kegiatan ini diikuti oleh 20 orang anak TK. Hasil dari kegiatan ini didapatkan bahwa semua anak TK Aisyiyah 
Bustanul Athfal memiliki pertumbuhan dan perkembangan yang sesuai dengan usianya saat ini, atau dengan kata lain anak-anak TK ini tidak mengalami keterlambatan ataupun penyimpangan daam tumbuh kembangnya.

3. Kegiatan pendidikan kesehatan tentang cara mencuci tangan yang benar diikuti oleh 32 orang yang terdiri dari anak-anak TK, guruguru serta mahasiswa dan Tim Pengabdian Masyarakat.

4. Kegiatan pendampingan aktivitas anak yang dilakukan selama di sekolah adalah pendampingan dalam belajar membaca, belajar mengaji, menggambar, senam sehat bersama, dan aktivitas bermain. Kegiatan pendampingan aktivitas anak ini bertujuan untuk menstimulasi kemampuan motorik kasar, motorik halus, interaksi sosial atau personal sosial anak dalam berinteraksi dan kemampuan pengolahan bahasa yang dimiliki anak.

5. Kegiatan lokakarya akhir dihadiri oleh kurang lebih 25 orang yang terdiri dari anak-anak TK, Kepala sekolah dan guru TK serta tim pengabdian masyarakat. Dalam kegiatan ini disampaikan laporan hasil seluruh kegiatan yang sudah dilakukan tim pengabdian masyarakat

\section{Saran}

Kegiatan penilaian tumbuh kembang anak di TK Aisyiyah Bustanul Athfal Kelurahan Sukamerindu Kota Bengkulu sebaiknya dilakukan secara rutin dan terus menerus dengan melibatkan pihak-pihak terkait seperti Dinas Kesehatan dan Puskesmas wilayah kerja setempat agar tumbuh kembang anak dapat terus dipantau sehingga apabila ditemukan adanya penyimpangan dalam pertumbuhan dan perkembangan anak dapat diatasi secara dini guna mencegah dampak lain yang lebih fatal. Diharapkan pula agar pihak-pihak terkait ini dapat memberikan pelatihan kepada para guru TK agar dapat menstimulasi pertumbuhan dan perkembangan anak didiknya sehingga anak didik akan memiliki tumbuh kembang yang optimal sebagai generasi penerus bangsa.

\section{DAFTAR PUSTAKA}

Desiyanto, F. A., \& Djannah, S. N. (2013). Efektivitas mencuci tangan menggunakan cairan pembersih tangan antiseptik (hand sanitizer) terhadap jumlah angka kuman. Jurnal Kesehatan Masyarakat (Journal of Public Health), 7(2).

Indonesia, K. R. (2015). Profil Kesehatan Indonesia tahun 2014. Jakarta: Kementerian Kesehatan RI, 1-382.

Kemenkes, R. I. (2016). Pedoman pelaksanaan stimulasi, deteksi dan intervensi dini tumbuh kembang anak di tingkat pelayanan kesehatan dasar. Jakarta: Kementerian Kesehatan RI.

Nursalam, N., \& Efendi, F. (2008). Pendidikan Dalam Keperawatan. Jakarta: Salemba Medika.

Sari, I. P. (2017). Mengembangkan Kreativitas Anak Usia Dini Melalui Permainan Melipat Origami Pada Siswa Kelompok B2 Tk Goemerlang Sukarame Bandar Lampung. IAIN Raden Intan Lampung.

Setyaningrum, R., Rofi'i, A., \& Setyanti, A. (2016). Tingkat Pengetahuan Dan Sikap Tentang Cuci Tangan Pakai 


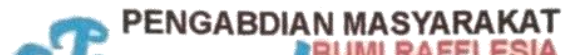 \\ Jurnoting}

Sabun (Ctps) Pada Siswa Sdn

Batuah I Dan Batuah III Pagatan.

Jurnal Berkala Kesehatan, 1(1).

Soetjiningsih, R. G. (2013). Buku

Tumbuh Kembang Anak Edisi 2.

Jakarta: Penerbit Buku Kedokteran

EGC.

Sugiono, S., \& Kuntjojo, K. (2016).

Pengembangan Model Permainan

Pra-Calistung Anak Usia Dini.

JPUD - Jurnal Pendidikan Usia

Dini, 10(2), 255-276.

https://doi.org/10.21009/jpud.102.04

Susilaningsih, E. Z., \& Hadiatama, M.

(2017). Pengaruh pendidikan

kesehatan terhadap perilaku

mencuci tangan siswa sekolah dasar.

Prosiding Seminar Nasional \&

Internasional.

Thaariq, N. A. A. (2014). Pengaruh

Pemberian Stimulasi Perkembangan

Motorik Kasar Dan Motorik Halus

Terhadap Perkembangan Bayi Usia

3-6 Bulan. 